TITLE:

\title{
NEW INVESTIGATIONS ON SYSTEMATICS AND EVOLUTION OF THE CLASS SCYPHOZOA AND THE PHYLUM CNIDARIA
}

\author{
$\operatorname{AUTHOR}(S)$ :
}

Werner, Bernhard

\section{CITATION:}

Werner, Bernhard. NEW INVESTIGATIONS ON SYSTEMATICS AND EVOLUTION OF THE CLASS SCYPHOZOA AND THE PHYLUM CNIDARIA. PUBLICATIONS OF THE SETO MARINE BIOLOGICAL LABORATORY 1973, 20: 35-61

\section{ISSUE DATE:}

1973-12-19

URL:

http://hdl.handle.net/2433/175791

RIGHT: 


\title{
NEW INVESTIGATIONS ON SYSTEMATICS AND EVOLUTION OF THE CLASS SCYPHOZOA AND THE PHYLUM CNIDARIA ${ }^{11}$
}

\author{
BERNHARD WERNER \\ Biologische Anstalt Helgoland, Zentrale Hamburg 50, Germany
}

With 10 Text-figures

\begin{abstract}
Contents

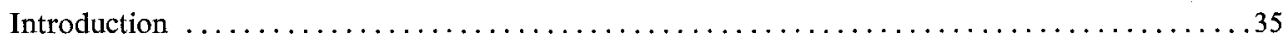

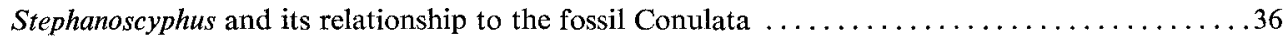

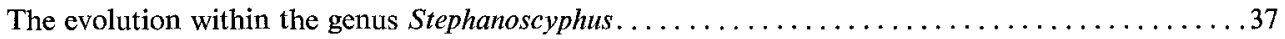

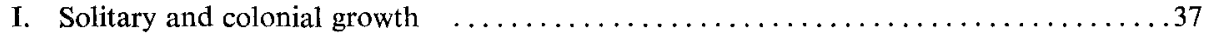

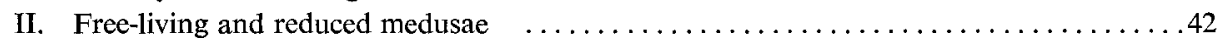

III. The opercular apparatus during strobilation $\ldots \ldots \ldots \ldots \ldots \ldots \ldots \ldots \ldots \ldots \ldots \ldots .49$

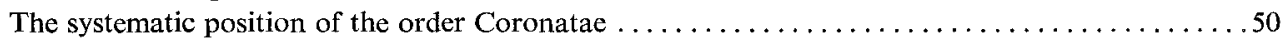

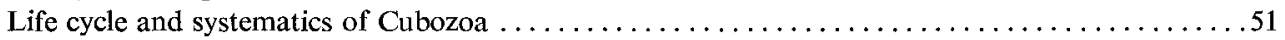

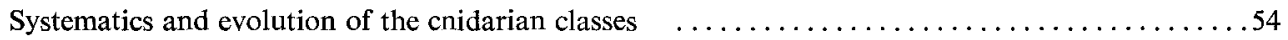

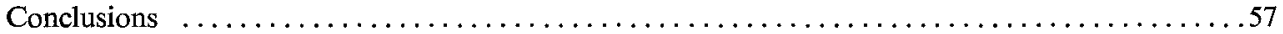

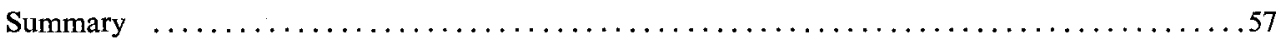

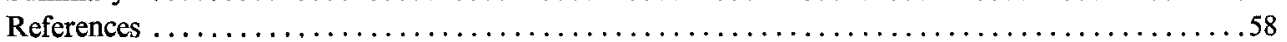

\section{Introduction}

The phylogeny of the lower groups of invertebrates has remained problematic up to the present day because the paleontological record has many gaps. In most cases there is no other means to follow the steps of evolution than by carefully investigating the morphology and life history of recent groups, to infer from the study of their homologies, the structures of their ancestors. It often happens that the facts can be interpreted in a different way for good reasons. Therefore the theories and hypotheses can lead to fairly different pictures of the evolution.

It is generally known that the Cnidaria are a classical example of this. As the lowest group of Metazoa they have attracted the extensive interest of zoologists. As a result there are many theories and hypotheses which deal with the role of this phylum with respect to the phylogeny of the lower invertebrates. From the point of comparative morphology, in the phylum Cnidaria the systematic position and succession of Hydrozoa, Scyphozoa, and Anthozoa was thought in earlier times to reflect the real steps of evolution in a well founded and inevitable way. There is only one fairly late serious attempt to change this succession. According to the hypothesis of HADŽI (1963) the Anthozoa which he derived from the Turbellaria should represent the most

1) Contributions from the Seto Marine Biological Laboratory, No. 568. 
primitive group, whereas, on the other hand, the Hydrozoa should be thought to have reached the peak of evolution because of their great variety of different structures and their enormous radiation into numerous groups. The controversy during the following years for and against HADži's hypothesis seemed to give no clear decision but finally, the evaluation of all previous as well as new results gave no support for the opinion of HADŽI so that the balance seemed to be in favour for the old classical theory again.

Chapman (1966), however, was led by his observations on the structures and behaviour of the scyphistoma, the polyp generation of the Scyphozoa, to the conclusion that this polyp represents the simplest cnidarian polyp. Though this author has not expressed the consequence that the Scyphozoa should be considered as being the most basic class of Cnidaria, during the following years new observations were made which gave strong support for this concept. The most important investigations which have promoted the new concept to a well founded theory concern the morphology, anatomy and life history of the scyphozoan polyp Stephanoscyphus (order Coronatae). This genus has been known for nearly one hundred years. Though the structure and life history of the Japanese species $S$. racemosus was described by KomaI (1935) and Komai and ToKuoka (1939) in an adequate way, the genus and its importance for the evolution of Cnidaria remained nearly unknown and unexploited. It was only in the last few years that the observations of WERNER (1966, 1967 a,b, 1970 a,b, 1971 a,b,c) based on rearing experiments with several species in the laboratory, gave strong evidence that Stephanoscyphus holds a key position in the systematics and evolution of the Scyphozoa and the phylum Cnidaria. The relevant data have been outlined particularly in the papers of WERNER $(1970 \mathrm{~b}, 1971 \mathrm{c})$ in which the combined results have been treated from the standpoint of comparative morphology and anatomy. Since then, more species could be included and new facts added, the most important of which is the elucidation of the life history of the cubomedusa Tripedalia cystophora (Werner, Cutress and Studebaker 1971). Therefore it should now be possible to follow the significant steps of evolution within the genus Stephanoscyphus and the class Scyphozoa, and to come to an adequate survey of the evolution of all cnidarian classes.

ChapMan (1966) has also indicated that Stephanoscyphus can be linked with the fossil extinct group of Conulata which are considered the ancestors of the recent Scyphozoa. The new observations on Stephanoscyphus enabled WERnER (1966, 1967 b, $1971 \mathrm{c}$ ) to support this relationship. Therefore a survey of the relevant results can give the starting point for the following phylogenetic concept. Further details on fine structure of Stephanoscyphus (CHAPMAN and WERNER 1972) lead to the same result that this genus represents the basic group of recent Scyphozoa and other Cnidaria.

\section{Stephanoscyphus and its Relationship to the Fossil Conulata}

Stephanoscyphus represents the sole scyphopolyp which possesses a firm peridermal tube completely enveloping the soft body. It is this primitive mark by which the polyp 
can be linked directly with the extinct fossil group of Conulata which were the ancestors of the recent Scyphozoa. The Conulata, long well known by their fossils to the paleontologists, represent a group of marine invertebrates which were fairly abundant from the Cambrian to Triassic. KIDERLEN (1937) and KNIGHT (1937) were the first to evaluate them as the ancestors of the recent Scyphozoa because of their marked tetramerous body structure. They came to this conclusion without knowledge of Stephanoscyphus. Comparing the details of the morphology, particularly of the peridermal structures of the Conulata on one hand, and of Stephanoscyphus on the other, WERNER (1966, 1967 b, $1971 \mathrm{c})$ has given good evidence for the validity of that theory, and Stephanoscyphus can be now considered as directly derived from the fossil ancestors. The recent polyp has proved a living fossil and a missing link keeping some essential characteristics of the Conulata though important changes have also taken place during evolution. On the other hand, the existence of Stephanoscyphus confirms the theory that the Conulata must be considered really as ancestors of the Scyphozoa, and more, we have now a much better understanding of the life habits of that extinct fossil group. As the significant observations and facts have been dealt with in the mentioned papers of Werner, there is no need to repeat all details. Glaessner (1971) has given a critical survey and has also supported the concept that the Conulata were the ancestors of the recent Scyphozoa though he has denied that they were themselves Scyphozoa.

\section{The Evolution within the Genus Stephanoscyphus}

\section{Solitary and Colonial Growth}

From the older literature and the systematic summaries of Leloup (1937) and KRAMP (1959, cf. WERNER 1967 a, p. 312), it is well known that there are solitary and colonial species of Stephanoscyphus. The solitary species which are described only from their peridermal structures are $S$. simplex KIRKPATRICK 1890 (which is thought by Kramp (1959) as synonymous to $S$. striatus, S. sibogae, S. bianconis) and S. corniformis KomaI 1936. But according to new informations given by NAUMOV (1959) and my own rearing experiments with several solitary species, S. simplex and $S$. corniformis cannot be considered as constituting valid species because a fairly good number of different species is hidden behind each of these names. Striking examples are the new species Stephanoscyphus eumedusoides (WERNER 1971 a, described as Tesseroscyphus eumedusoides, see below p. 45) and Stephanoscyphus planulophorus (WERNER 1971 b). All new observations have shown that it is necessary to elucidate the complete life cycle of a given species in order to find out its true systematic position and to reveal its relationship with the medusa generation. In several cases solitary species of Stephanoscyphus belong to the medusa genus Nausithoë. It is well known that the first described species Nausithoë punctata KöLLIKER 1853 originates from the 
colonial polyp Stephanoscyphus mirabilis ALLMAN 1874. In another case a species belonging apparently to the solitary species $S$. corniformis has been shown to produce medusae of the genus Atorella (WERNER 1967 a). It must be pointed out that according to the nomenclatory rules, the species of Stephanoscyphus must be given the name of the medusa if this has been described earlier. An example has been already mentioned with the species Nausithoë punctata (S. mirabilis).

There are also some colonial species: the above mentioned Nausithoë punctata KöLliker 1853, Stephanoscyphus allmani KIRKPATRICK 1890, S. racemosus KomAI 1936 and S. komaii Leloup 1937. As will be shown later (see below p. 43) new observations gave the result that $S$. racemosus possesses eumedusoids; therefore, the species name remains unchanged. In the cases of $S$. allmani and $S$. komaii ${ }^{2}$ the medusa generation has not been described up to now; therefore, the names remain valid until the knowledge of the medusae in the future will make it necessary to change the species name eventually.

Taking into account the well known idea that the early cnidarian form was a motile so li tary planuloid animal, there can be no doubt that a solitary polyp represents the stem form of the recent Cnidaria if one goes back far enough in time. On the other hand, the colonial habit must be considered as having originated by progressive evolutionary steps due to the acquisition of a sessile way of life. As mentioned before, there are solitary and colonial species of Stephanoscyphus. If the several species can be arranged in a series of progressive complication which starts with the solitary ones, it seems quite reasonable to believe that the series reflects the steps of evolution which has taken place in the past.

A species of Stephanoscyphus from the Indian Ocean can serve as an example for typical solitary species. It has been described in the first papers (WERNER 1966, 1967 a,b) as belonging to Nausithoë punctata because the medusae which were raised in the laboratory up to maturity were similar to the latter medusan species. But by later rearing experiments it could be confirmed that true Nausithoë punctata are originated from the Mediterranean colonial polyp Stephanoscyphus mirabilis as mentioned above. Therefore, the probably new species from the Indian Ocean has been denominated later in a preliminary way as Stephanoscyphus spec. 1 (WERNER 1970 a, see the note of the systematic situation and correction on p. 162). This species which has been demonstrated by photos several times in the mentioned papers can be characterized by its large size (up to $8 \mathrm{~cm}$ ), the well developed peridermal tube, and the small attaching disk (Fig. 1 a).

Stephanoscyphus komaii LeLoup 1937 follows as the most elementary form of colonial species (Fig. 1 c, Fig. 2 a-d). The material has been collected at La Parguera, Puerto Rico, in November 1971 and has proved excellent for culture experiments. The species has a well developed basal stolonial plate (=scyphorhiza) from which the

2) In my cultures some polyps of $S$. komaii did strobilate in the normal way giving rise to freeswimming ephyrae. But it was not possible to raise the young medusae up to maturity. 

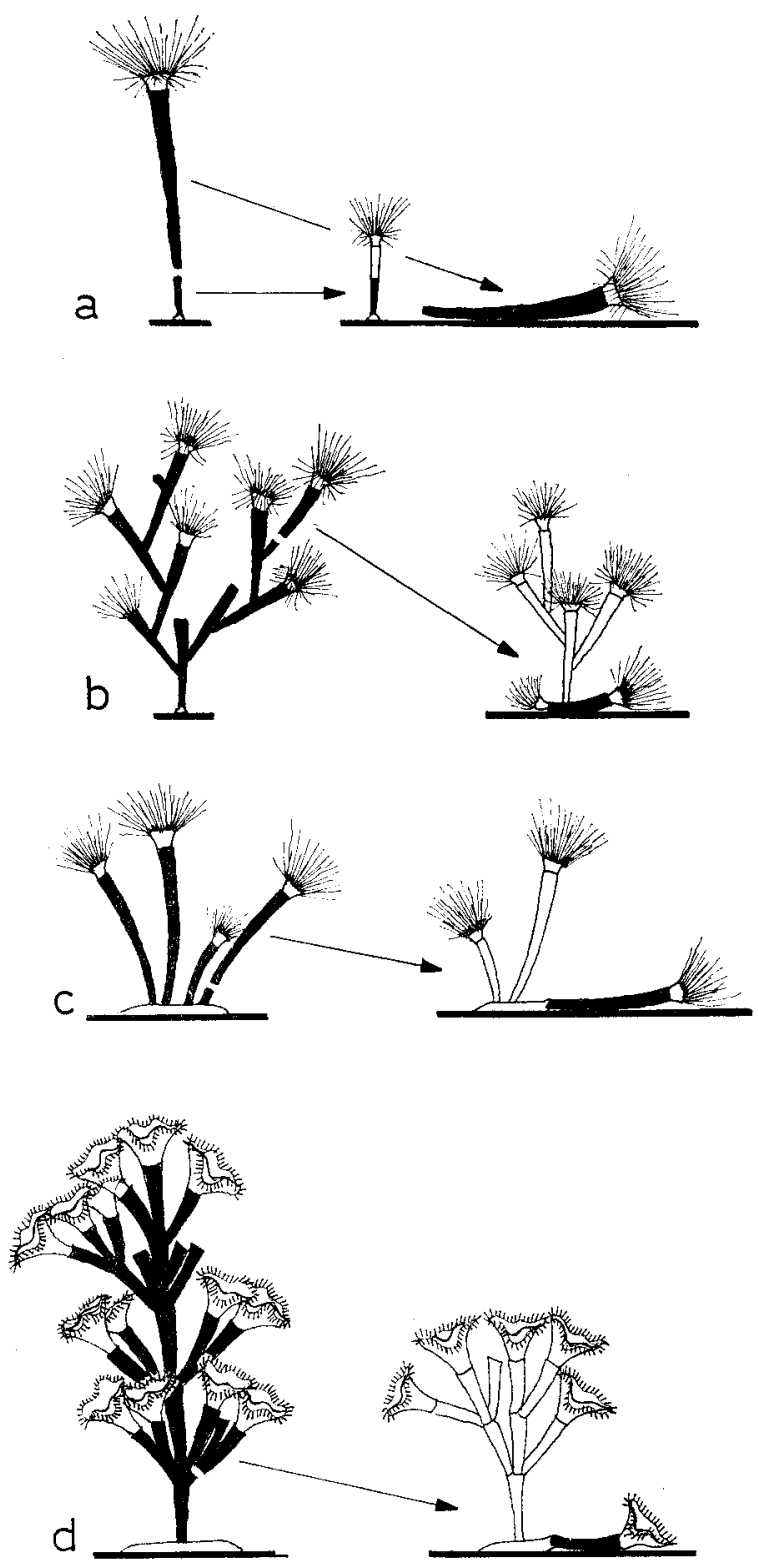

Fig. 1 a-d. Left side: solitary and colonial growth of several species of Stephanoscyphus; (a) the solitary species S. spec. 1 from the Indian Ocean, (b) Nausithoë punctata, (c) S. komaii, (d) S. racemosus. Note the different size of the solitary species and the single polyp of the colonial species. Right side: result of the experiment of cutting off a specimen near its base; black the separated polyp, white the new regenerated colonies which are formed in (b) from the separated polyp, in (c) and (d) from the newly produced scyphorhiza. 


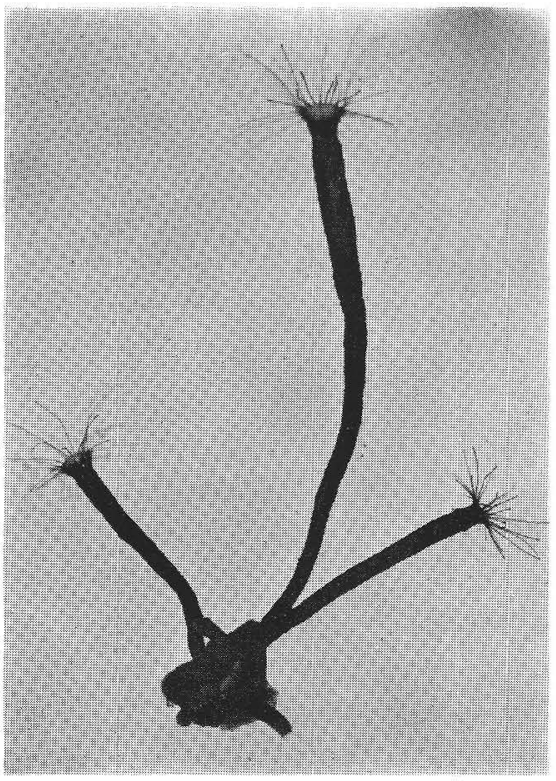

a

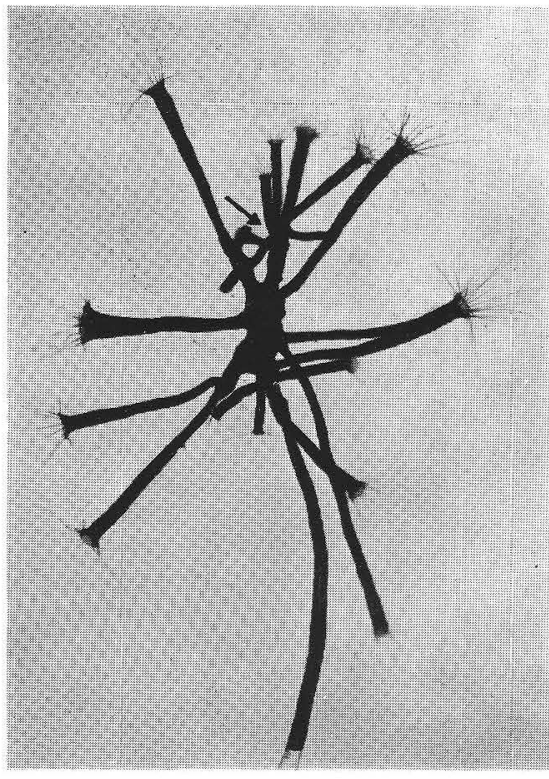

c

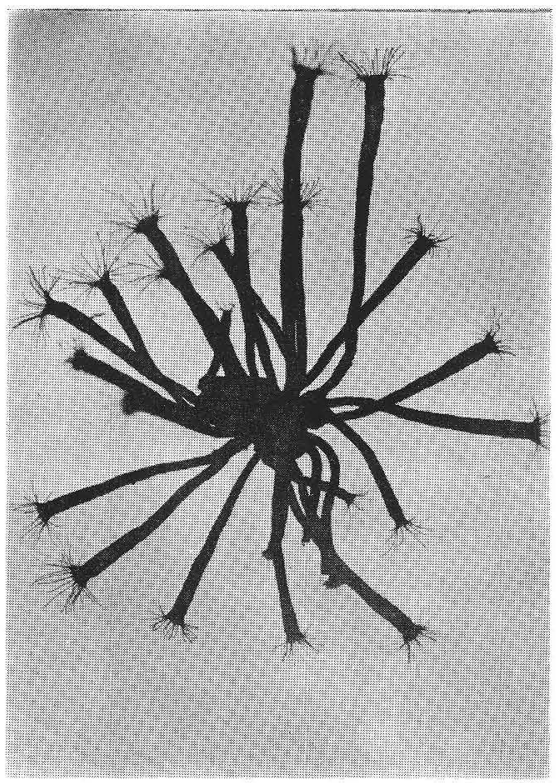

b

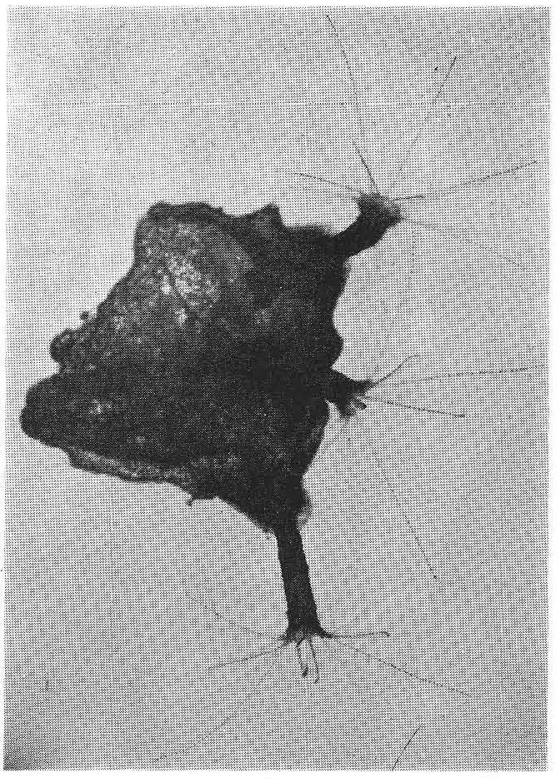

d

Fig. 2 a-d. Stephanoscyphus komaii. (a) young colony which has developed from a single polyp (the biggest one) after the formation of a new scyphorhiza (central basal part); (b) fully developed colony; (c) colony with pseudobranching (at arrow); (d) result of the second experiment: from a piece of soft body without periderm a large scyphorhiza has developed which gave rise to 3 young polyps. 
single unbranched polyps take origin. The long-term rearing experiments have ascertained that this species has only true stolonial colonies with unbranched polyps. In some cases a pseudobranching has been observed (Fig $2 \mathrm{c}$ at the arrow) but this phenomenon is due to an "autoepizoism" (MILlard 1973): new stolonial cell material from the scyphorhiza creeps to higher levels at the outer surface of a polyp's tube and gives rise to a new polyp which is erected from the older and bigger polyp which serves only as a substratum.

The next step is given by the species Nausithoë punctata KöLliker 1853 (Fig. 1 b) in which the individual polyp can branch but in a simpler way which is called the racemose type of branching. From the point of evolution the phenomenon of branching itself depends on the new acquisition of an ability to dissolve the peridermal tube at distinct points by the activity of special enzymes in order to give rise to new budding polyps. On the other hand, Nausithoë punctata proved more primitive than Stephanoscyphus komaii because of the former's lack of a scyphorhiza and because the former's small attachment disk is similar to that of the solitary species.

The peak of the colonial growth by branching has been reached by the species Stephanoscyphus racemosus Komai 1935 (Fig. 1 d). In this species the type of branching is of a higher order as has been described by Komai (1935, cf. Werner 1970 b). The colonies represent large stems in which whorls of numerous secondary polyps are formed at several branching points at higher vertical levels. Therefore, the large colonies of $S$. racemosus resemble colonies of corals. As in $S$. komaii, the colonies of $S$. racemosus originate from a well developed scyphorhiza which possesses the ability to produce flat stolonial outgrowings to form a coarse network.

The argument given only in a descriptive way that within the genus Stephanoscyphus the progressive steps of evolution can be followed from the solitary to the colonial species, can be confirmed by some simple experiments. They have revealed that the species exhibit different degrees of morphogenetic potencies which correspond exactly with the solitary or colonial way of growth.

As already described (WERNER $1970 \mathrm{~b}$ ), the first simple experiment is carried out in that a single polyp is cut off near its base in a solitary as well as in a colonial species. The results of this simple experiment are demonstrated in Fig. 1 on the right. As illustrated in Fig. 1 a the upper part (black) of the solitary polyp which is separated from its base does not undergo any change. It lies on the bottom and all that can be observed is that the hole of its base will be closed by a sheet of periderm which is secreted by the soft body after the closure of the wound. It must be added that the stump (black) which is attached to the substratum is able to regenerate a new head (white) and to undergo further growth.

In the colonial species the result of the same experiment is quite different. It can be observed that there are differences between the species which correspond to the different type of colonial growth. As the second step the species Nausithoe punctata should be noted (Fig. 1 b). In this species a new head will be produced from the basal 
hole of the separated polyp, and furthermore, the polyp is able to branch again and to build up a new colony (white). But this new colony is not able to attach to the substratum and to produce a new basal attachment disk.

The other two species Stephanoscyphus komaii and $S$. racemosus behave in a different way because they possess higher morphogenetic and regenerative qualities. From the basal hole of the separated polyp new undifferentiated cell material grows out, attaches to the substratum and produces a new well developed scyphorhiza from which new single individual polyps (in $S$. komaii, Fig. 1 c) or new branched colonies (in $S$. racemosus, Fig. $1 \mathrm{~d}$ ) originate. In Fig. $1 \mathrm{c}$ and $1 \mathrm{~d}$ the regenerated new colonies are illustrated in white. From this simple experiment it can be concluded that the colonial growth is correlated with higher morphogenetic potencies due to progressive steps of evolution. It is of interest that the two species $S$. komaii and $S$. racemosus which possess the well developed scyphorhiza and proved to exhibit the more advanced regenerative qualities also have numerous symbiotic zooxanthellae in their endodermal cells which give them a brown colour.

The second simple experiment which has also been described earlier (WERNER $1970 \mathrm{a}, \mathrm{b}$ ) gave a corresponding result. If the soft body of a polyp is removed from the peridermal tube, it undergoes a de- and reorganization by which the separated part of the soft body with its head and crown of tentacles will change into a thin lens-shaped plate of cell material which attaches to the substratum and is enveloped with a thin peridermal cover secreted by the ectodermal cells. According to the present results, there occur in the solitary species from the Indian Ocean $S$. spec. 1 no further changes or developmental processes, and the transformed piece of the soft body finally dies. In the colonial species on the other hand, new polyps will be produced from the basal plate and they will give rise to new colonies. This has been shown in the abovementioned papers for Nausithoë punctata and S. racemosus (WERNER 1970 b, Fig. 9 and Fig. 10) and could be confirmed by new experiments in exactly the same way for S. komaii (Fig. 2 d). Again this simple experiment reveals the higher morphogenetic and regenerative qualities of the colonial species.

The descriptive and experimental results lead to the conclusion that in the genus Stephanoscyphus evolution has started with the solitary species and later given rise to the colonial forms.

\section{Free-living and Reduced Medusae}

As described by Lo Bianco and Mayer (1890), Komai (1935) and Werner (1966, 1967 a,b) Stephanoscyphus has proved to be a true scyphopolyp as it produces medusae in the normal way by the process of strobilation which undergoes principally the same phases well known from the similar process in the scyphistoma of the orders Semaeostomeae and Rhizostomeae. The process in Stephanoscyphus differs in that there is in most species the formation of an opercular apparatus which closes the tube aperture during strobilation (see below p. 49). This difference can be attributed to the pos- 
session of the peridermal tube. In all investigated species the strobilation has proved o. the polydisc type which gives rise, at least in some species, to enormous numbers of medusa larvae (ephyrae). To give two striking examples: in S. spec. 1 from the Indian Ocean the number of ephyrae produced in one bout of strobilation amounts from several hundred to about thousand in fully grown polyps, whereas in Atorella the polyp can produce up to five thousand very small ephyrae. As in the scyphistoma, the polyp of Stephanoscyphus is able to regenerate and to strobilate again. The ephyrae detach in the larval stage and possess no signs of gonads. The development up to full size and maturity takes about three months in the investigated species which possess a free-living medusa generation.

The outlined way of development conforms with the method of development typical in the orders Semaeostomeae and Rhizostomeae. According to the present knowledge in these two orders there is only one exception: i.e. the phenomenon of medusa formation without strobilation. This is the case in the genus Pelagia in which the polyp generation is suppressed completely. On the other hand, it is only in the order Coronatae that there are metagenetic species in which the mode of medusa production differs from the mentioned one. In the cases to be dealt with, the phase of the planktonic life of the medusa generation can be shortened or completely reduced. By the comparative consideration of the differences found in the degree of the reduction phenomena, the species can be arranged in a series of changes which correspond to the progressive steps of evolution reflected as well in the medusa generation.

From the observations of Komar (1935) and KOMAI and ToKUOKA (1939) it is known that in $S$. racemosus the development exhibits some important differences as the germ cells are produced and ripen in the gastric septa of the polyp. Thus in the process of strobilation, which is quite normal, the developing young medusae are directly and immediately supplied with ripe germ cells. Parts of the polyp's gastral septa constitute the gonads of the medusae. As these authors were not able to follow the fate of the medusae and to elucidate the complete life cycle, a partial problem of this special type of medusa production remained unsolved. It was not until the summer of 1971 that the present author succeeded in carrying out new investigations on the reproduction of $S$. racemosus. Thus the observations of KomaI and ToKUOKA (1939) could be completed.

From the descriptions of these authors it was already known that the medusae, though mature, were morphologically not fully developed as they lacked some structures typical for ripe medusae of true metagenetic species. The detached medusae of $S$. racemosus have no gastric filaments nor have they a fully developed mouth or any tentacles. From this difference, therefore, it could be supposed that they could not represent true medusae but only medusoids with a restricted life span. This could be confirmed by the new unpublished observations which are to be described briefly.

First, they revealed differences in the behaviour of the male and female medusoids. It could be directly observed and is demonstrated in Fig. 3 that the male medusoids 
are able to release the spermatozoa before having detached from the strobilation chain. In the drawn special case it has been observed that the medusoid last but one must have released the spermatozoa earlier than the distal medusoid did, because the former's gonads were shrunken, whereas the upper distal medusoid had still fully developed gonads. Komar (1935) has seen exactly the same phenomenon but he was not able to

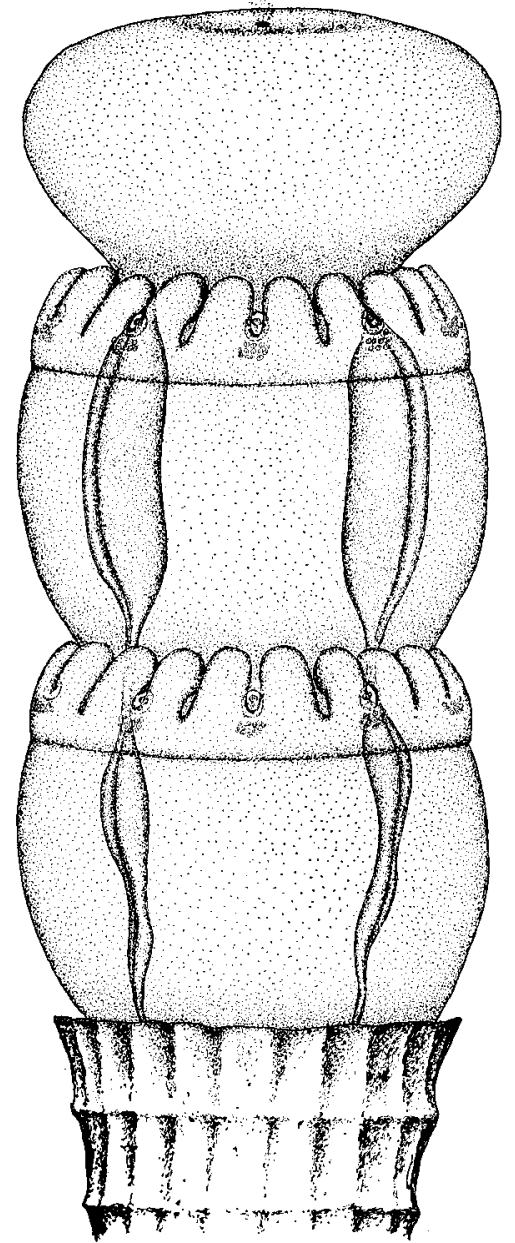

Fig. 3. Stephanoscyphus racemosus, strobila of a male polyp just in the phase of shedding off spermatozoa from the central opening of the operculum. Drawn by F. HECKMANN.

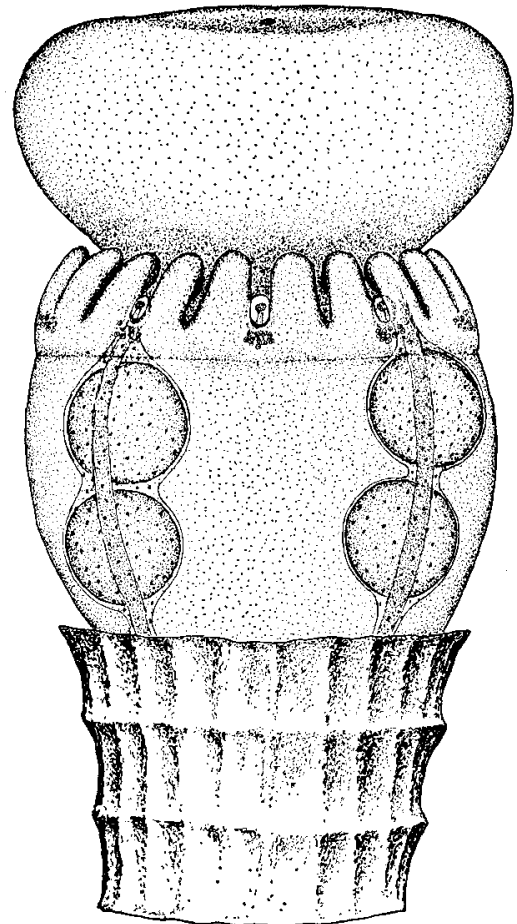

Fig. 4. Stephanoscyphus racemosus, strobila of a female polyp showing only the distal eumedusoid outside the tube. Note the large size of the ripe eggs in the gonads the spots of which are zooxanthellae. Drawn by F. HeCKMANN, 
give the adequate explanation as he could not follow the spawning habits of the medusoids.

On the other hand, the fully developed female medusoids (Fig. 4) must detach before they are able to shed large eggs from their mouths. As illustrated in Fig. 5, the eggs are embedded after their release within some mucus which contains nematocytes with fully developed and functional nematocysts. According to the observations, the detached female medusoids are not able to swim in a co-ordinated manner though they have a fairly well developed muscular system which enables them to do contracting movements and to press out the eggs. They are found lying on the surface of the colonies to which they adhere apparently by the sticky mucus of the egg masses. In the cultures the medusoids were also seen lying on the bottom of the glass dishes. Having shed the germ cells, the detached male and female medusoids die after two or three days.

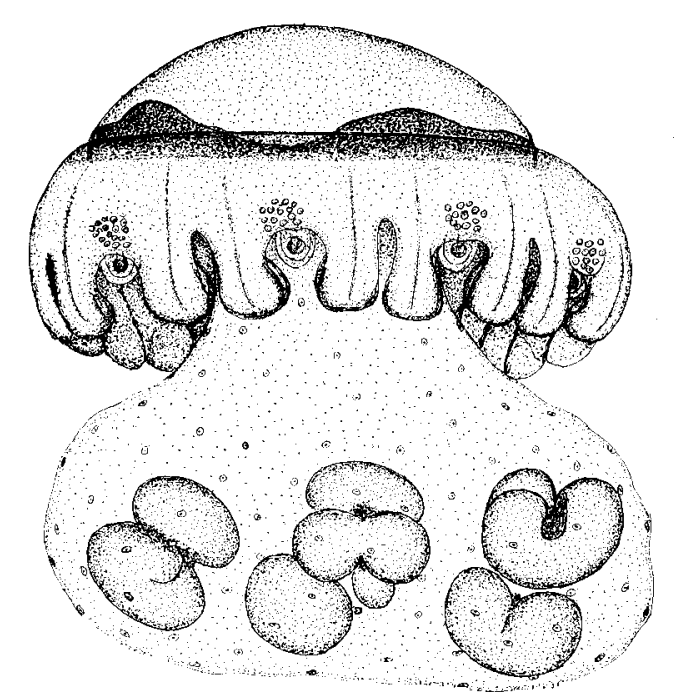

Fig. 5. Stephanoscyphus racemosus, detached female eumedusoid which has shed off the eggs. They are embedded in a mass of mucus and start the cleavage. Drawn by F. HECKMANN.

Considering the morphological structures and the life history of the medusoids of S. racemosus, and using the terminology of KüHN (1913) for the several stages of reduction of gonophores in hydroids we are dealing with eumedusoids in our scyphozoan species. The gonophores possess essential structures of the medusa generation but others are lacking. Furthermore, as the most significant feature, the duration of life of the free-living phase has been shortened in a marked way though there is a difference between the male and female sexes.

A more advanced stage of reduction occurs in the new species Stephanoscyphus eumedusoides which has been given the name of a new genus Tesseroscyphus in the 
preliminary description (WERNER 1971 a). The reason was that the medusoids possess some characteristics by which they differ in a marked way from the ephyra-like offsprings of most other species of Stephanoscyphus. But a more detailed investigation of the medusoids led to the conclusion that the differences are the result of a progressive reduction also in this new species which, therefore, must be grouped with Stephanoscyphus. The details will be published in another paper which is in preparation.

In $S$. eumedusoides the solitary polyp undergoes the normal phases of strobilation giving rise to a strobila of about three to five, maximally eight medusoids. But these are not detached at all as they become mature and reproduce in the strobilation chain which remains in close connection with the basal part of the polyp. The fully developed medusoids have a bell-shaped umbrella, possess 4 gastric filaments, 8 solid short tentacles and weakly developed marginal lappets without sensory organs. Each medusoid of the chain develops 4 gonads. As has been already described (WERNER 1971 a, p. 352) there are different stages of hermaphroditism as the single medusoid

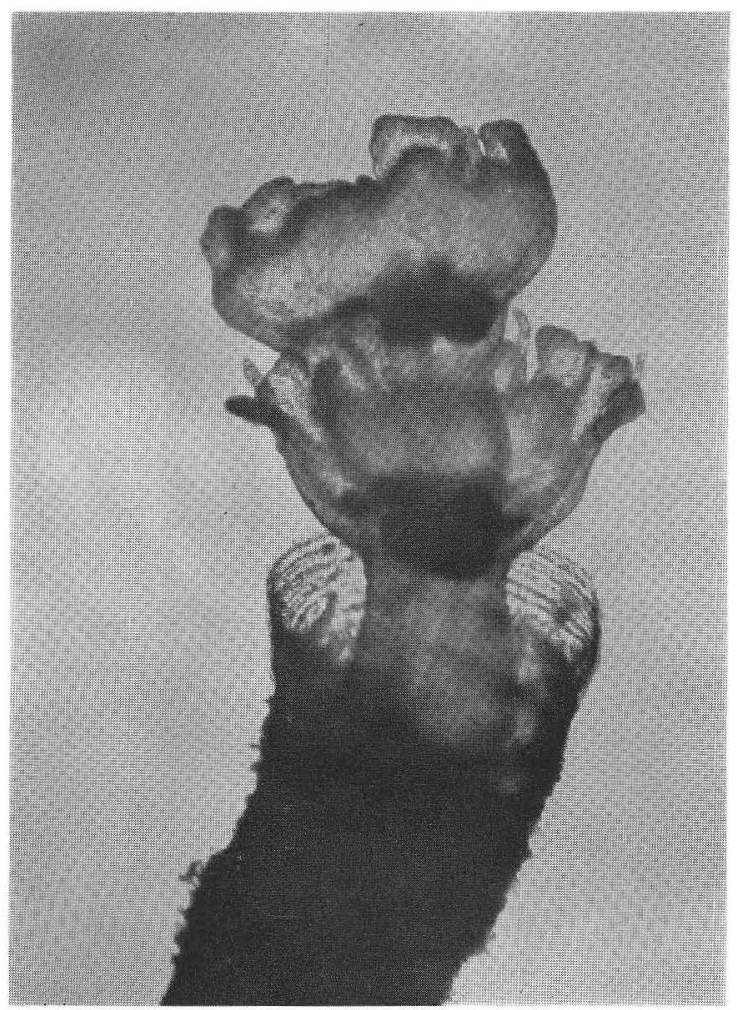

Fig. 6. Stephanoscyphus eumedusoides, final phase of strobilation in which the chain of eumedusoids has been pushed out from the tube aperture by the regenerating polyp. Note the bellshape of the umbrella and its weakly developed marginal structures. 
of the chain can have gonads of one or two sexes, and the same gonad can produce both sexual products. The ripe eggs and spermatozoa are released into the gastral cavity where fertilization and development into free-swimming planulae take place. These leave the chain actively from the mouth of the most distal medusoid or get free if the medusoids degenerate and die. The regenerating polyp finally pushes the chain of medusoids out of the tube (Fig. 6). According to their structures and life history they represent a type of eumedusoids but of a more advanced (= regressive) stage than in $S$. racemosus.

The new species Stephanoscyphus planulophorus (WERNER 1971 b) which has been collected together with $S$. eumedusoides in submarine caves of the rocky shore near Marseille (Mediterranean Sea) reveals the most advanced stage of reduction as the medusa generation occurs only as a transitional phase of the strobilation process but is finally suppressed completely. In this solitary species the polyp undergoes first the normal phases of strobilation (Fig. $7 \mathrm{a}, \mathrm{b}$ ) but the ephyrae do not become free to start the planktonic way of life. They detach from the strobila within the peridermal tube

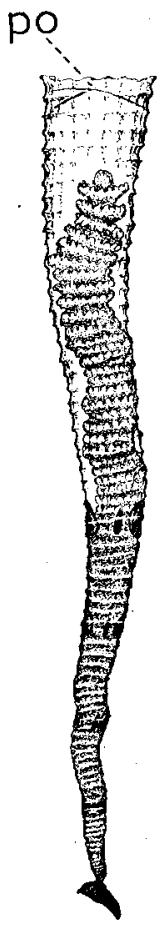

a

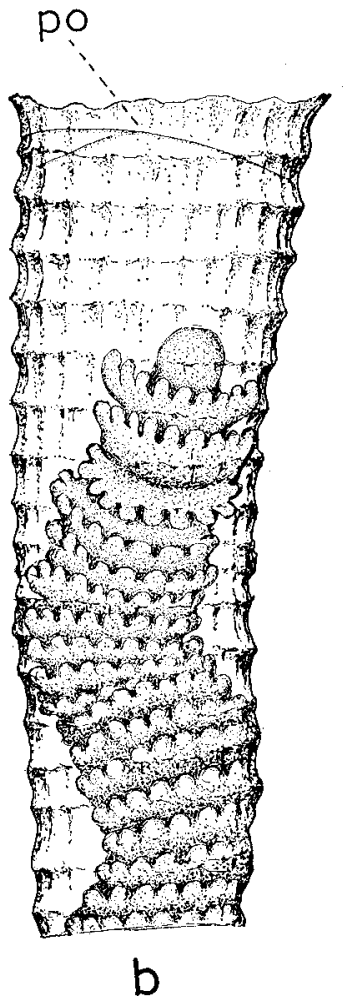

Fig. 7 a,b. Stephanoscyphus planulophorus, (a) young strobila which exhibits the shape of the ephyra-like early stages, (b) part of the same polyp. po, peridermal operculum.

Drawn by F. HeckManN. 
which is closed completely by a peridermal operculum. The ephyrae can be recognized as being of this larval stage because they have marginal lappets and even exhibit some weak contracting movements. After being detached from the strobilation chain they undergo a direct transformation into flagellated free-swimming planulae (Fig. 8 a,b). After a fairly long incubation period the operculum of the tube will be broken away,

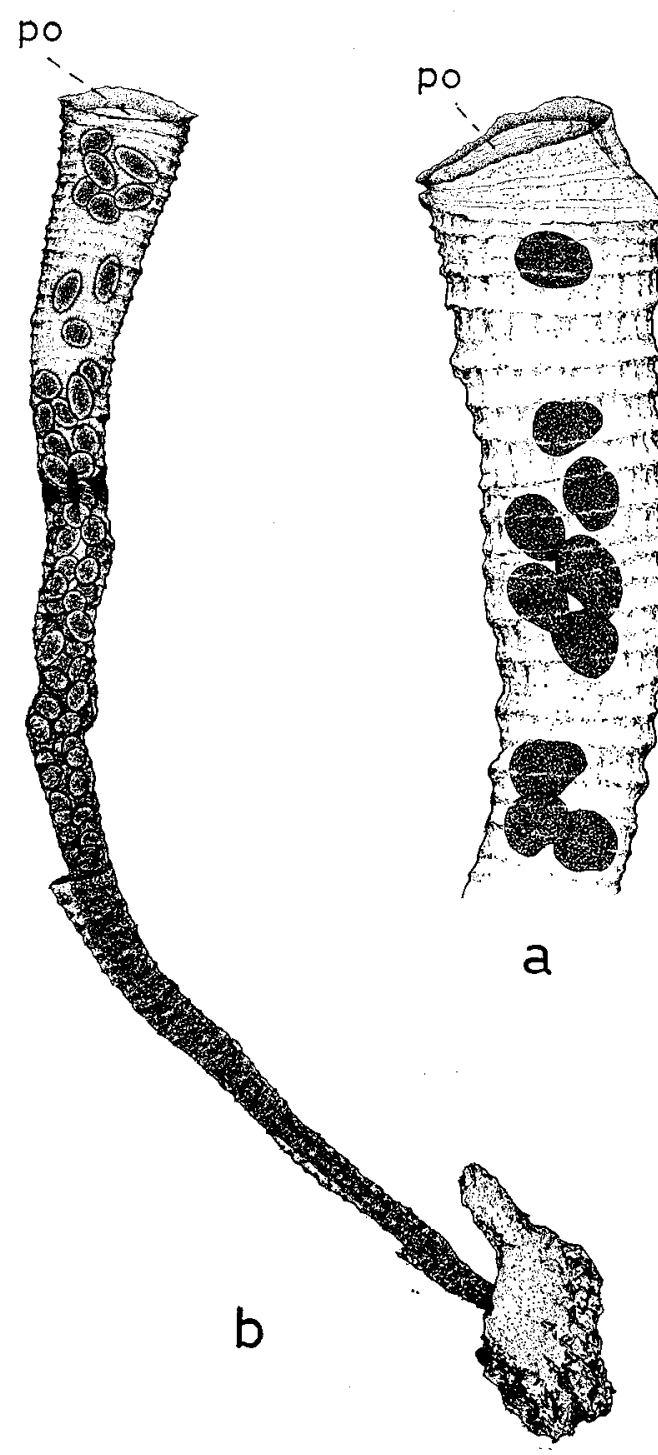

Fig. 8 a,b. Stephanoscyphus planulophorus, final phases "of strobilation. From WeRNER 1971 b, Fig. 6 a,b. Note in (a) the intermediate stage of the transformation of the ephyrae into planulae, in (b) the fully developed flagellated planulae. po, peridermal operculum. 
sometimes by the accumulating planulae, sometimes by the regenerating polyp. In this way the planulae swim out of the tube and start the planktonic period of two to five weeks, and finally they attach to the substratum and transform into young polyps.

This unusual way of development has been observed now in more than one hundred specimens and follows exactly the described mode in all cases. The most striking phenomenon is that no sign of sexual reproduction could be observed up to now. S. planulophorus represents the first known example of a scyphopolyp in which the medusa generation is suppressed completely. The progressive advantage which is given in all described three cases of medusa reduction consists of the shortening of the planktonic period which is most critical because of predation.

It is of general interest that there is no correlation of the reduction of the medusa generation and the solitary or colonial habit. The colonial species Stephanoscyphus komaii $^{3)}$ and Nausithoë punctata produce free medusae in the normal way and are true metagenetic species. The colonial species $S$. racemosus gives rise to eumedusoids as does the solitary species $S$. eumedusoides, whereas in the other solitary species $S$. planulophorus the medusa generation is lacking. Furthermore, it must be noted that $S$. racemosus occurs in its natural habitat in the highest level of the upper sublittoral zone, in a depth of about 5 to $10 \mathrm{~m}$. The two other species $S$. eumedusoides and $S$. planulophorus are found to occur in submarine caves in a depth of about $20 \mathrm{~m}$. So it seems reasonable to attribute the aberrant ways of development to have evolved under the influence of special environmental conditions as adaptations. In such cases it seems possible to correlate the steps of evolution with the selective effects of the environment.

\section{The Opercular Apparatus during Strobilation}

In the investigated species of Stephanoscyphus a further series of evolutionary steps can be followed with respect of the formation of the opercular apparatus during strobilation. As is described by WERNER $(1966,1967 \mathrm{a}, \mathrm{b})$ the basic phenomenon has been detected in several species from the Indian Ocean for which $S$. spec. 1 can serve as example again. The phenomenon and the correlated processes are as follows. In the beginning phase of strobilation the head of the polyp with the tentacles will be reduced to form an opercular apparatus which completely closes the tube aperture. It consists in the fully developed stage of a disk of cell material which secretes a thin sheet of periderm on the outer surface. In the initial stage the cellular operculum remains connected with the chain of developing ephyrae but later it separates from the most distal ephyra. If the ephyrae are ripe enough to escape by active swimming movements from the polyp's tube, the cellular operculum degenerates and will be finally detached from the wall and cast out of the tube. The outer peridermal sheet of the operculum on the other hand, will be detached also from the wall of the tube

3) See the footnote on p. 38. 
by the swimming ephyrae and can be found later on the outside as a thin circular disk.

The comparative observations on the formation of the operculum of several other species have revealed differences which can be arranged into a series of progressive reduction. This has been done in detail in an earlier paper (WERNER 1970 a). In the intermediate stage which has been observed to occur in Nausithoë punctata and Stephanoscyphus racemosus an opercular apparatus is formed which consists only of cell material without the outer peridermal sheet. The cellular operculum will be lost by its detachment and final degeneration as described for S. spec. 1. A more progressive stage is realized in a solitary species from the Meteor-Bank, Atlantic, called in a preliminary way $S$. spec. 7 , and also in $S$. komaii. In these species a peridermal operculum is also lacking; but the well developed cellular operculum does not detach from the chain of ephyrae and does not degenerate as it is resorbed completely by the most distal ephyra. This final stage can be observed also in the species $S$. eumedusoides. Therefore, in the most advanced cases there is no longer any principal difference when compared with the corresponding process in the scyphistoma of Semaeostomeae and Rhizostomeae. As is generally known, in the scyphistoma the head with the tentacles is resorbed during strobilation in the same way into the most distal ephyra.

It seems of interest to remark that from the species without an operculum it becomes clear that the process of strobilation can undergo all phases in the normal way so that the operculum is not necessary and has no functional value for that process. This seems to give evidence that this structure must be interpreted as an old inheritance from the ancestors, the fossil Conulata, which has survived in a changed form. Furthermore, special attention must be called to the result that the described series of progressive reduction of the opercular apparatus ends in a type which is realized also in the scyphistoma. Therefore, with respect of the treated special structure, an evolutionary line can be followed which leads from Stephanoscyphus to the scyphistoma. This confirms the conclusion that both polyps have had common ancestors.

\section{The Systematic Position of the Order Coronatae}

There are more characteristics which support the mentioned result, and a careful comparison between Stephanoscyphus and the scyphistoma on one side, and the coronate medusae and semaeostome and rhizostome medusae on the other, confirms the conclusion of NAUMOV (1961) that polyps and medusae of the Coronatae possess more primitive characteristics than the scyphistoma and the medusae of Semaeostomeae and Rhizostomeae. A detailed comparison has been outlined by WeRnER (1971 c, table 1, p. 234) and it seems unnecessary to repeat all facts. It may however be mentioned that the loss of the peridermal tube in the scyphistoma which has but a thin basal peridermal cup can be explained satisfactorily as a progressive reduction which has been compensated by the new acquisition of a well developed cellular mesoglea. 
In Stephanoscyphus the mesoglea is present as an acellular thin mesolamella. On the other hand, both polyps have principally the same tetramerous construction of the soft body with 4 gastral septa and 4 gastral pockets. The other common feature-the possession of the peculiar muscular system consisting of 4 interradial longitudinal muscle strands which are located within the gastral septa can be explained as an old unchanged inheritance from the common ancestors, the Conulata (KIDERLEN 1937). For this extinct fossil group the possession of a similar tetramerous muscular system can be deduced from the necessity of having their tube aperture closed by 4 triangular flaps which must have had 4 corresponding muscles.

There is one more interesting characteristic by which the relationship of Stephanoscyphus and the scyphistoma, and also the more primitive position of the former can be demonstrated. As described in the older literature (LeLoup 1937, KRAMP 1959) and redescribed for several species by WERNER (1966, 1967 a,b, 1971 b) the inner wall of the tube of Stephanoscyphus possesses rows of symmetrically arranged thorn-like projections called teeth. In most species there are several rows of teeth in different vertical levels.

In the reduced small basal peridermal cup of the scyphistoma there are correspondingly no signs of teeth but with an exception. It seems of evolutionary interest that in one species belonging to the Semaeostomeae, namely in Cyanea palmstruchi, there is a small but fairly well developed peridermal basal cup which contains one row of teeth as well (WIDERSTEN 1969).

From this characteristic it becomes clear again that Stephanoscyphus with the well developed long peridermal tube and the scyphistoma with the reduced (but in one case fairly marked) basal peridermal cup must have had common ancestors. All results indicate that Stephanoscyphus must be considered as the more primitive polyp revealing a closer relationship to the common ancestors, the Conulata, which are known from their large tubes. After all, the Coronatae represent the most basic order of the class Scyphozoa.

The new results lead to the other consequence that the Stauromedusae cannot be considered as being a basic order of Scyphozoa. Their supposed close relationship to the Cubomedusae (UCHIDA 1929) needs new interpretation in the light of the observations on the life history and systematics of Cubozoa.

\section{Life Cycle and Systematics of Cubozoa}

The Cubomedusae are inhabitants of the neritic zones of tropical oceans. They were grouped by most zoologists with the Scyphozoa because their body exhibits a marked tetramerous structure. Only few authors have pointed to the special features by which the Cubomedusae proved an aberrant group (MAYER 1910, p. 500, cf. UCHIDA 1929, pp. 183).

Actually, the systematic position of the Cubomedusae remained enigmatic as the 
polyp generation and the most essential phase of the life cycle, the formation of the medusa generation, remained unknown. It was just two years ago that the complete life cycle of a cubomedusan species could be cleared up by successful rearing experiments. The results have been published in a preliminary way by WERNER, CUTRESS and Studebaker (1971). As the most surprising result, the polyp of Tripedalia

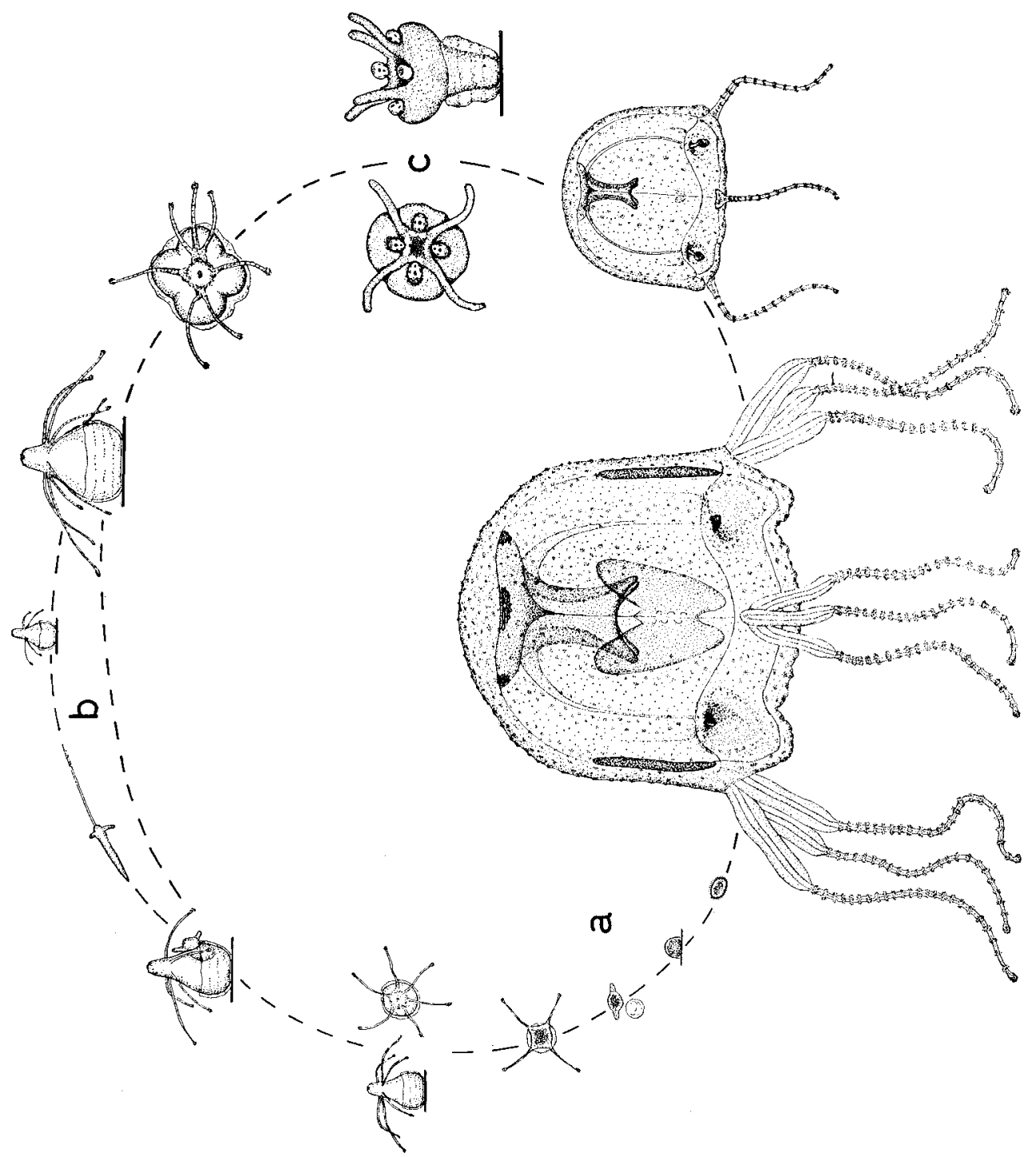

Fig. 9. Life cycle of the cubomedusa Tripedalia cystophora, (a) development of the planula into a young sessile primary polyp, (b) asexual reproduction of the polyp by lateral budding off small secondary polyps, (c) metamorphosis of the fully grown polyp into one single medusa; view on the oral pol (left) and side view (right). Drawn by F. HeckmanN. 
cystophora has proved completely different from the coronate polyps of Stephanoscyphus as well as from the scyphistoma of the Semaeostomeae and Rhizostomeae. The solitary polyp of Tripedalia cystophora possesses a clear radial-symmetrically constructed body which exhibits no signs of a tetramerous structure at all (Fig. 9). The typical scyphozoan structures such as the possession of 4 gastric septa and 4 gastric pockets, and also of 4 interradial longitudinal muscle strands are lacking completely. There are some more significant characteristics by which the polyp of $T$. cystophora is separated from the scyphozoan polyp. This is true for the asexual reproduction which is marked by the production of small secondary polyps. They are formed by a process of lateral budding which is similar to that well known in the fresh-water Hydra. Furthermore, the development of $T$. cystophora is unique as the polyp undergoes a true metamorphosis and transforms into just one medusa. The first step of metamorphosis can be recognized in the change of the former radial structure of the polyp's body to a tetramerous one with 4 quadrants. This characteristic can be interpreted as do some others that the cubopolyp must be derived from scyphozoan ancestors. According to all observations which will be outlined in detail in a later paper, the Cubozoa can never be Scyphozoa, but, instead, they represent an evolutionary link between the Scyphozoa and Hydrozoa, and it is necessary to give them the systematic rank of a class (Fig. 10).

New observations have added interesting facts which also point out the Cubozoa as a separated and most specialized group. By longterm rearing experiments it was possible to raise the young medusae of Tripedalia cystophora after their metamorphosis up to full size and maturity. In ripe medusae, both sexes could be identified easily by the different colour and structure of the gonads. Furthermore, they could be shown to possess a special and peculiar mating behaviour which is unknown for all other Scypho- and Hydromedusae. In the gonads of the ripe male of $T$. cystophora the spermatozoa are joined together to form spermatozeugmata of a simple type. Numerous spermatozeugmata are enclosed into globular spermatophores which are formed within grooves at the 4 corners of the stomach. Then the spermatophores are transfered directly to the female in a mating process in which the male and female cling together each with one tentacle. This special mating behaviour corresponds to the well known phenomenon (CONANT 1898) that the females of Tripedalia cystophora are larviparous as their eggs are fertilized and develop within the gastral pockets of the umbrella into planulae. These new results (WERNER 1973) confirm that in the Cubozoa the specialization of all known groups of medusae has reached the peak.

From the knowledge of the life history and systematics of the Cubozoa it also follows that there cannot be any close relationship to the Stauromedusae. As has been outlined by UCHIDA (1929, cf. THIEL 1966), the Stauromedusae combine polypoid and medusoid structures, and it is important that the basal polypoid part is principally tetramerously constructed, whereas the upper medusoid part is octomerous. Though there are some similarities when compared with the Cubomedusae, the differences 
prevail. Characteristics which are typical for Scyphozoa, as for instance, the possession of the coronal muscle (a) and of the separated longitudinal septal muscles (b), which are lacking in the cubomedusa (A) and in the radial cubopolyp (B), confirm the true scyphozoan nature of the Stauromedusae.

\section{Systematics and Evolution of the Cnidarian Classes}

The systematics of a given group must reflect its phylogeny and the steps of evolution which has taken place in the past. The conclusive interpretation of the real facts which are gathered here in order to elucidate the evolution of the phylum Cnidaria is based on the concept that no recent group can be derived from any other recent group, but instead they must be derived from common ancestors.

Because the cnidarian classes but the Anthozoa are represented by two generations of the sessile asexual polyp and the free-swimming sexual medusa the basis for every phylogenetical concept refers to the question which generation should be considered the more primitive. The fact, that, according to all knowledge, no medusa has ever existed in the Anthozoa and the other fact that in the regular development of the Scyphozoa and Hydrozoa the medusa originates from the polyp, should have given satisfactory evidence for that the polyp represents the primary generation. But, as is well known, an extensive discussion of that problem has been in the past. It was only in the last few years that a comparative evaluation of all facts led to the conclusion that the polyp must be considered as being the stem form of all recent Cnidaria. A detailed argumentation has been given by HADžı (1965) though from his viewpoint of the turbellarian origin of the Cnidaria. Chapman (1966) and Thiel (1966, cf. UCHida 1969, Werner 1971 c) have explained satisfactorily why, at least in the Scyphozoa, the polyp must represent the primary form.

As has been mentioned above (p. 36), CHapman (1966) was led by his investigations particularly on the neuromuscular system and behaviour of the scyphistoma, to the consequence that this scyphopolyp must be thought as being the simplest cnidarian polyp. With respect to this basic position the scyphistoma must be replaced now by Stephanoscyphus, as the newer observations on the fine structure gave the same result (CHAPMAN and WERNER 1972). Therefore, a Stephanoscyphus-like polyp must now be considered as the most primitive form of the recent Cnidaria.

This concept, the consequences of which are important for the following considerations, confirms the old classical idea of the medusa as being nothing else than a detached polyp which has changed to a free-swimming way of life by adaptations. This statement has been expressed nearly 100 years ago in the golden age of morphology by Weismann, Richard and Oskar Hertwig, Haeckel and others from the point of the homology of structures and has found today more convincing support. First of all, taking into account the development of the Cubozoa, we are able to follow directly the change of the sessile polyp into one free-swimming medusa! 
A further support comes from the comparative evaluation of anatomical structures. The anatomy of Stephanoscyphus is unique by the possession of an endodermal canal system which is located in its capitulum just below the tentacular crown, and which consists of an horizontal closed ring canal and 4 short vertical perradial canals connecting the ring canal with the coelenteron. Considering the general criteria of special structures and localization we cannot doubt that the canal system of Stephanoscyphus is homologous to that of the coronate medusae, and principally, also to that of the semaeostome medusae in its first ontogenetical stage, and finally also to that of the hydromedusae. Therefore, in the genus Stephanoscyphus the polyp forwards directly the canal system to the medusa in the process of strobilation, and this peculiar structure must have had its first origin in the polyp generation.

In the scyphistoma (a) and in the hydropolyp (b) we are confronted with the facts that (a) a tetramerous polyp which has no canal system but has in the septal ostia what can be thought as being its remnants, and (b) a radial polyp without any sign of a canal system possess the latent ability to produce structures with a corresponding canal system but this ability is restricted to the process of medusa formation. We must add the remark that in the old classical concept of the most primitive nature of the hydropolyp, there was no satisfactory explanation for the mentioned fact, and the question which is important from the point of evolution remained enigmatic and unsolved: why is a radial polyp able to produce a tetramerous offspring? But now in the light of the observations on Stephanoscyphus the conclusion seems to be justified that the ancestors of the scyphistoma as well as of the hydropolyp must have had a corresponding canal system.

This leads to further consequences that the radially constructed hydropolyp must be derived from tetramerous ancestors, and that a tetramerous sessil polyp must be considered as stem form of all recent Cnidaria. It is of interest that REMANE (1954) has noted in a general survey of the evolution of the cnidarian classes that the lack of septa in the hydropolyp cannot be a truely primitive mark because the developing medusa has gastral pockets and septa! This author has concluded that the hydropolyp must be simplified by secondary steps of evolution which are correlated to the strong tendency of colonial growth and the diminution of size of the single polyp.

Considering all facts and observations the final conclusion seems to be inevitable that the Scyphozoa and not the Hydrozoa represent the most basic cnidarian class. WERNER (1971 c) has discussed briefly some other relevant data which support this result. That the Anthozoa represent the recent cnidarian polyps with the most complicated structures and behaviour needs no discussion. Furthermore, there seem to be no principal difficulties to derive that class from tetramerous ancestors. The Anthozoa differ from the Scyphozoa in the possession of an ectodermal gullet which is no doubt a secondary acquisition. The same is true for the well developed cellular mesoglea and mesogleal structures of the Anthozoa. We have seen (p. 50) that the possession of a cellular mesoglea is not a primitive but a progressive characteristic of 
the scyphistoma, and therefore this characteristic cannot be retained as constitutive in the class diagnosis of the Scyphozoa. Apparently also the phenomenon of bilaterality of the Anthozoa represents a new acquisition due to enlargement of size and the necessity of an intensified water circulation as has been noted by HYMAN (1940).

On the other hand, the Scyphozoa and Anthozoa have some important characteristics in common: (a) the germ cells are originated within the endodermal layer and shed out from the mouth, (b) the endoderm is formed by invagination. Taking also into account the lack of the medusa generation in the Anthozoa, it seems reasonable to suppose that in the evolutionary line the branching point into the divergent lines of the two classes must be localized not so far from the common ancestors. (Fig. 10).

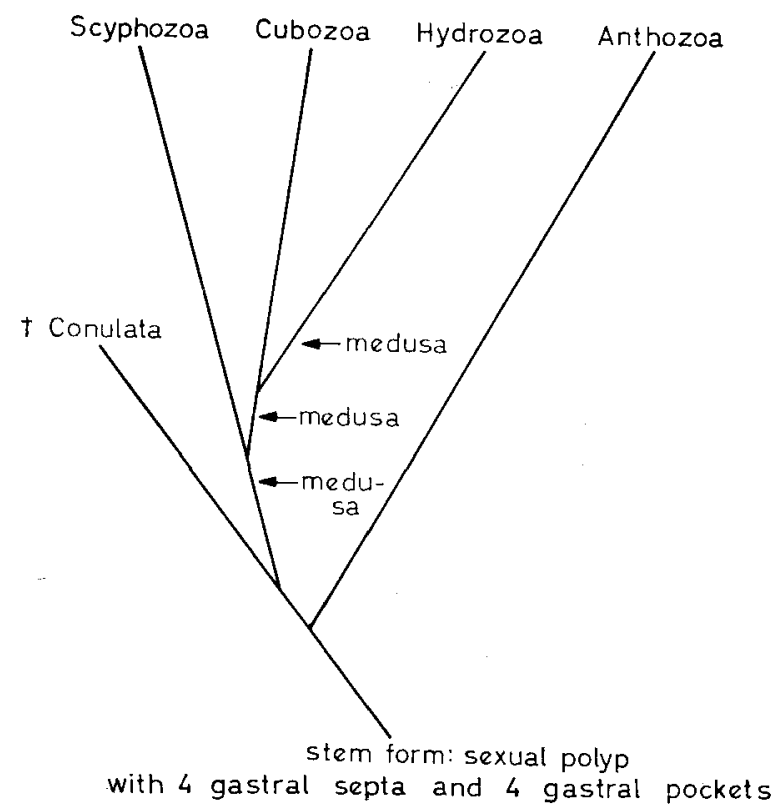

Fig. 10. Diagrammatical survey of the relationships of the classes of the phylum Cnidaria.

It must be noted also that the Hydrozoa represent the group with the greatest diversity of morphological structures, complex life histories and different habitats (HADŽI 1963, UCHIDA 1963). Another interesting viewpoint results from new investigations of PASSANo (1973) who was able to demonstrate that, with respect to the neurophysiology, the scyphomedusae have simpler structures than the hydromedusae. The fact that the Scyphozoa have the simplest nematocyst equipment (WEILL 1934, WERNER 1965) regarding the number and quality of nematocyst categories, conforms well with the final result that they take the most basic position of the recent cnidarian classes. 


\section{Conclusions}

The comparative considerations indicate that a solitary sessile sexual polyp which is tetramerous by the possession of 4 gastral septa and 4 gastral pockets represents the stem form of all recent Cnidaria. Therefore, the tetrasymmetry is the general basic morphological principle of body construction in this phylum. The scyphomedusae, cubomedusae, and hydromedusae are detached polyps which have changed by adaptation to a free-swimming way of life.

The diagram in Fig. 10 illustrates the relationships between the recent classes at the present state of knowledge: the Scyphozoa represent the basic class whereas the Cubozoa take an intermediate position between the Scyphozoa and Hydrozoa. The hydropolyp must be considered as simplified by secondary steps of evolution. The Anthozoa are apparently an early offspring of the common ancestors.

After all, the real changes which have taken place in the evolution from the common ancestors to the recent classes of Cnidaria indicate that it was in the polyp generation that the transspecific and macro-evolution has become effective. Including the Ctenophora and interpreting the Coelenterata in the whole phylogenetic system, the present author is of the opinion that they must be considered as a blind-ending side branch from which no other group of invertebrates can be derived.

\section{Summary}

1. The investigations on the morphology and life history of Stephanoscyphus (Scyphozoa, Coronatae) based on longterm rearing experiments, gave the result that this polyp holds a key position in the evolution of Scyphozoa and Cnidaria. Stephanoscyphus is the sole scyphopolyp with a firm peridermal tube which envelops completely the soft body. It is this primitive mark by which the polyp can be linked directly with the extinct fossil Conulata being the ancestors of the recent Scyphozoa. Stephanoscyphus represents a living fossil and missing link.

2. The evolution within the genus Stephanoscyphus has been outlined. The observations on the solitary and colonial growth have revealed that the species can be arranged in a series of progresssive changes which starts from solitary and ends in colonial species with well branched polyps. Species with a stolonial colony and unbranched polyps represent an intermediate stage. The colonial species have greater morphogenetic and regenerative potencies than the solitary ones.

3. Considering the development and life habits of the medusa generation it has been shown that there is a series of evolutionary changes as well. The normal development which is characterized by a free-swimming medusa generation is changed to the formation of sessile medusoids. In the most advanced stage no medusa exists at all as the larval ephyrae undergo a direct development into planulae. 
4. The process of formation of the opercular apparatus which closes the polyp's peridermal tube during the strobilation exhibits interspecific differences which reflect a further progressive series of reduction. In the most advanced case, in which the opercular apparatus will be resorbed into the distal ephyra the situation is similar to that present in the scyphistoma, the polyp of the orders Semaeostomeae and Rhizostomeae.

5. The comparison of Stephanoscyphus and the coronate medusae on one side, and the scyphistoma and the semaeostome and rhizostome medusae on the other, gives the result, that the Coronatae represent the most basic order of the class Scyphozoa.

6. The knowledge of the complete life cycle of the cubomedusa Tripedalia cystophora leads to the conclusion that the Cubozoa are no Scyphozoa but represent an evolutionary link between the Scyphozoa and Hydrozoa.

7. The relationships of the recent cnidarian classes are outlined according to the present state of knowledge. The combined results lead to the consequence that the Scyphozoa represent the most basic class and that a Stephanoscyphus-like polyp must be considered as the basic form of the recent Cnidaria.

8. All considerations conform well with the theory that a solitary sessile sexual polyp with 4 gastral septa and 4 gastral pockets represents the stem form of all recent Cnidaria and that the tetramery is the basic morphological principle in this phylum.

\section{Acknowledgement}

The author is indebted very much to Dr. David M. Chapman, Halifax, Canada, who read the manuscript and corrected the English.

\section{REFERENCES}

Allman, G. J., 1874. On the structure and systematic position of Stephanoscyphus mirabilis, the type of a new order of Hydrozoa. Trans. Linn. Soc. Lond. (Ser. 2: Zool.) 1, 61-66.

Chapman, D.M., 1965. Co-ordination in a scyphistoma. Am. Zool. 5, 455-464.

Chapman, D.M., 1966. Evolution of the scyphistoma. In: The Cnidaria and their Evolution. Ed. by W.J. Rees. Acad. Pr. Lond. (Symp. zool. Soc. Lond. 16, 51-75).

Chapman, D.M. and Werner, B., 1972. Structure of a solitary and a colonial species of Stephanoscyphus (Scyphozoa, Coronatae) with observations on periderm repair. Helgoländer wiss. Meeresunters. 23, 393-421.

Conant, F.S., 1898. The Cubomedusae. Mem. biol. Lab. Johns Hopkins Univ, 4, 1-61.

Glaessner, M.F., 1971. The genus Conomedusites Glaessner \& WADE and the diversification of the Cnidaria. Paläont. Z. 45, 7-17.

HadżI, J., 1963. The Evolution of the Metazoa. Pergamon Pr., Oxford, 499 pp.

HADẑI, J., 1965. The polyp as the fundamental and primary form of Cnidaria. Raspr. slov. Akad. Znan. Umet. 8, 1-53.

HaEckel, E., 1880. Das System der Medusen. I, 2: System der Acraspeden. Gustav Fischer, Jena. $361-672$.

Hyman, L.H., 1840. The Invertebrates: Protozoa through Ctenophora. McGraw-Hill Book Comp., New York and London, 726 pp. 
Kiderlen, H., 1937. Die Conularien, über Bau und Leben der ersten Scyphozoen. Neues Jb. Mineral. Paläont., Beil. Bd. 77B, 113-169.

Knight, J.B., 1937. Conchopeltis WalcotT, an Ordovivian genus of Conularidae. J. Paleont. 11, $186-188$.

Komat, T., 1935. On Stephanoscyphus and Nausithö̈. Mem. Coll. Sci. Kyoto Univ. (Ser. B) 10, 289-339.

KomaI, T., 1936. On another form of Stephanoscyphus found in the waters of Japan. Mem. Coll. Sci. Kyoto Univ. (Ser. B) 11, 175-183.

Komat T., and Tokuoka, Y., 1939. Further observations on the strobilation of Stephanoscyphus. Mem. Coll. Sci. Kyoto Univ. (Ser, B) 15, 127-133.

Kramp, P.L., 1959. Stephanoscyphus (Scyphozoa). Galathea Rep. 1, 173-185.

KüHN, A., 1913. Entwicklungsgeschichte und Verwandtschaftsbeziehungen der Hydrozoen, I. Die Hydroiden. Ergebn. Fortschr. Zool. 4, 1-284.

Leloup, E., 1937. Hydropolypes et Scyphopolypes recueillis par. C. Dawydoff sur les côtes de l'Indochine française. Mém. Mus. r. Hist. nat. Belg. (Sér. 2) 12, 1-73.

Lo Bianco, S. and MaYer, P., 1890. Spongicola and Nausithoë. Zool. Anz. 13, 687--688.

Mayer, A.G., 1910. Medusae of the World: Publs. Carnegie Instn., 109, 735 pp.

Millard, N.A.H., 1973. Auto-epizoism in South African hydroids. Publ. Seto Mar. Biol. Lab. 20 (Proc. Second Internat. Symp. Cnidaria), 23-34.

Naumov, D.V. 1959. Species differences of polypoid stages of Coronomedusae. (In Russian) Dokl. Akad. Nauk SSSR 126, 602-604.

NaUmov, D.V., 1961. Scyphomedusae of the Seas of the USSR. In: Tables for the Determination of the Fauna of the USSR. (In Russian). Opred. Faune SSSR 75, 1-72.

Passano, L.M., 1973. Behavioral control systems in medusae; a comparison between hydro- and scyphomedusae. Publ. Seto Mar. Biol. Lab. 20 (Proc. Second Internat. Symp. Cnidaria), $615-645$.

ReEs, W.J., 1957. Evolutionary trends in the classification of capitate hydroids and medusae. Bull. Brit. Mus. (Nat. Hist.), Zool. 4, 455-534.

Remane, A., 1954. Die Geschichte der Tiere. In: Heberer, G., Die Evolution der Organismen. Bd. 1, 340-422. Gustav Fischer, Stuttgart.

THIEL, Hj., 1966. The evolution of Scyphozoa. A review. In: The Cnidaria and their Evolution. Ed. by W.J. Rees, Acad. Pr. Lond. (Symp. zool. Soc. Lond. 16, 77-117).

Uchida, T., 1929. Studies on the Stauromedusae and Cubomedusae, with special reference to their metamorphosis. Jap. J. Zool. 2, 103-193.

UCHIDA, T., 1963. The systematic position of the Hydrozoa. Jap. J. Zool. 14, 1-14.

UCHIDA, T., 1969. The interrelationships of scyphozoan class. Bull. Mar. Biol. Stat. Asamushi, Tôhoku Univ. 13, 247-250.

WeILl, R., 1934. Contribution à l'étude des Cnidaires et de leurs nématocystes. I, II. Trav. Stn zool. Wimereux 10, 11, 1-701.

Werner, B., 1965. Die Nesselkapseln der Cnidaria, mit besonderer Berücksichtigung der Hydroida I. Klassification und Bedeutung für die Systematik und Evolution. Helgoländer wiss. Meeresunters. 12, 1-39.

Werner, B., 1966. Stephanoscyphus (Scyphozoa Coronatae) und seine direkte Abstammung von den fossilen Conulata. Helgoländer wiss. Meeresunters. 15, 317-347.

Werner, B., 1967 a. Morphologie, Systematik und Lebensgeschichte von Stephanoscyphus (Scyphozoa Coronatae), sowie seine Bedeutung für die Evolution der Scyphozoa. In: Verh. dt. zool. Ges. Göttingen 1966, Zool. Anz. Suppl. Bd. 30, 297-319.

Werner, B., 1967 b. Stephanoscyphus Allman (Scyphozoa, Coronatae), ein rezenter Vertreter der Conulata? Paläont. Z. 41, 137-153.

WERNER, B., 1970 a. Weitere Untersuchungen uber die Entwicklungsgeschichte von Stephanoscyphus (Scyphozoa, Coronatae) und seine Bedeutung für die Evolution der Scyphozoa. In: Verh. dt. 
zool. Ges. Würzburg 1969, Zool. Anz. Suppl. Bd. 33, 159-165.

WeRner, B., 1970 b. Contribution to the evolution in the genus Stephanoscyphus (Scyphozoa Coronatae) and ecology and regeneration qualities of Stephanoscyphus racemosus Komat. Publ. Seto Mar. Biol. Lab. 18, 1-20.

WERNER, B., 1971 a. Ein neuer, bisher unbekannter Entwicklungsmodus bei einem Scyphopolypen. Experientia 27, 351-353.

WeRnER, B., 1971 b. Stephanoscyphus planulophorus n. spec., eine neuer Scyphopolyp mit einem neuen Entwicklungsmodus. Helgoländer wiss. Meeresunters. 22, 120-140.

Werner, B., 1971 c. Neue Beitraege zur Evolution der Scyphozoa und Cnidaria. Acta salmant. I. Ciencias. 36, 223-244 (I. Simpos. intern. Zoofilogenia).

Werner, B., 1973. Spermatozeugmen und Paarungsverhalten bei Tripedalia cystophora (Cubomedusae). Mar. Biol. 18, 212-217.

Werner, B., Cutress, Ch. E. and Studebaker, J.P., 1971. Life cycle of Tripedalia cystophora Conant (Cubomedusae). Nature (Lond.) 232, 582-583.

Widersten, B., 1969. Development of the periderm and podocysts in Cyanea palmstruchi Swartz 1809. Zool. Bidr. Upps. 38, 51-60.

\section{DISCUSSION}

UCHIDA: Dr. WERNER's talk was very interesting and instructive. May I ask you the following two questions? 1) It is generally known that in the Hydrozoa the Thecata are more highly differentiated than the Athecata. Do you think the primitive scyphopolyp has the theca, or not?

2) The polyp of Cubomedusa is very similar to that of Gonionemus, but the latter gives rise to medusabuds. It is generally accepted that the Rhizostomeae are more differentiated than the Semaeostomeae. The Rhizostomeae proliferate by monodiscal strobilation, while the Semaeostomeae proliferate by polydiscal strobilation. The metamorphosis of Cubomedusa seems to be somewhat similar to the monodiscal strobilation. How do you think about the correlation between the metamorphosis in Cubomedusa and monodiscal strobilation in Rhizostomeae?

WERNER: 1) Yes, this is indeed an important problem. Considering the Scyphozoa, I believe to have shown by the comparative observations that Stephanoscyphus with a peridermal tube or theca represents the more primitive polyp, whereas the scyphistoma with a reduced theca must be derived from ancestors which have had also a well developed theca.

In the Hydroidea the Thecata represent with no doubt the more progressive group. The evolution of their more complicated peridermal structures can be explained sufficiently as being correlated with the high degree of branching which is typical for this group. But on the other hand, the structures of the thecae are quite different between Scyphozoa and Hydrozoa. Therefore one must conclude that in the more advanced Hydrozoa an evolution of new structures has taken place. According to a well known phylogenetic rule, lost characteristics will not be repeated in the way of evolution as identical structures, but evolve as new different structures.

2) Yes, this is important, too. There are some observations which indicate that the metamorphosis of the cubopolyp into one medusa only can be derived from the process of monodiscal strobilation which is typical in the Rhizostomeae. The first indication that the cubopolyp starts to transform into the medusa consists of the change of the former radial structure into the tetramerous one. This phenomenon leads to the conclusion that the cubopolyp is to be derived from scyphozoan ancestors. Furthermore, I have observed that in the metamorphosis of Charybdea there occurs about in $2 \%$ of all cases one phenomenon which makes the metamorphosis similar to a monodiscal strobilation. In those cases, the very elongated basal part of the polyp body, which is normally completely absorbed into the apex of the developing medusa, can be divided accidentally into two pieces. The upper part undergoes in the normal way the transformation, whereas the more basal part regenerates into a small polyp, which grows to a fully developed polyp and can undergo the metamorphosis into one 
medusa. This phenomenon is not normal but occurs only accidentally and may be explained as atavism.

Millard: Does Dr. Werner think that the hydrozoan polyp is derived from Stephanoscyphus, and is there any evidence of tetramerous symmetry in the hydrozoan polyp?

Werner: No, I don't believe that the hydrozoan polyp can be derived from Stephanoscyphus. All what can be said is only that the scyphozoan polyp and the hydrozoan polyp have had common ancestors. With regard to signs of tetramerous symmetry in the hydrozoan polyp one can refer to the folds of endoderm of the hypostome of hydroids, which are very often tetramerous in cross-section; furthermore the number of tentacles of the primary polyp is often four, and the most important is that the developing medusa bud which is at least for sometime a part of the polyp, has the well known tetramerous structure.

WEILL: Did you actually observe in Stephanoscyphus planulophorus an ephyra undergoing its metamorphosis and changing into a planula? How much time does it take?

WERNER: Yes, it has actually been observed, also by isolating a single ephyra. It takes about three to five days.

EdWards: Concerning the tetramery commonly found in Scyphozoa and Hydrozoa, while I agree that this may be construed as evidence probably supporting evolutionary relationships, I suggest that tetramery is maintained by its functional advantage. Not rarely, trimerous, pentamerous, hexamerous and other aberrant specimens occur in tetramerous scyphomedusae and hydromedusae, but these are not so functionally successful as the normal tetramerous form and do not become genetically adopted by the species. I interpret tetramery as maintained because of its functional advantage over other structural forms, and accordingly this is a reason for its persistent occurrence in these groups of Cnidaria.

WERNER: I cannot agree. From the point of function, a pentamerous structure for instance could provide just in a similar way an advantage like the tetramerous structure. The point of discussion is not why the Cnidaria and their ancestors have developed the tetramerous structure but only that they have, and that the recent Cnidaria have overcome the tetramerous basic symmetry as a genetically fixed inheritance from their ancestors.

Thiel: (Comment on the question of Dr. EDwards). One should not put too much weight on scyphomedusae with abnormal number of radial canals in evolutionary questions. These medusae develop as ephyra parts or spiral ephyra in tetramerous strobilae and the ephyrae regenerate into medusae with a lower or a higher number of radial canals. This does not allow evolutionary conclusions from non-tetramerous medusae.

WERnER: That is true. 